Article

\title{
The Use of Feed Additives to Reduce the Effects of Aflatoxin and Deoxynivalenol on Pig Growth, Organ Health and Immune Status during Chronic Exposure
}

Alexandra C. Weaver ${ }^{1}$, M. Todd See ${ }^{1}$, Jeff A. Hansen ${ }^{1,2}$, Yong B. Kim ${ }^{3}$, Anna L. P. De Souza ${ }^{2}$, Teena F. Middleton ${ }^{4}$ and Sung Woo Kim ${ }^{1}{ }^{1} *$

1 Department of Animal Science, North Carolina State University, Raleigh, NC 27695, USA;

E-Mails: acchayto@ncsu.edu (A.C.W.); todd_see@ncsu.edu (M.T.S.); jeffhansen@murphybrownllc.com (J.A.H.)

2 Murphy-Brown LLC, Rose Hill, NC 28458, USA; E-Mail: anadesouza@murphybrownllc.com

3 Department of Population Health \& Pathobiology, North Carolina State University, Raleigh, NC 27695, USA; E-Mail: youngbaek_kim@ncsu.edu

4 Ag ProVision LLC, Kenansville, NC 28349, USA; E-Mail: tmiddle@aol.com

* Author to whom correspondence should be addressed; E-Mail: sungwoo_kim@ncsu.edu; Tel.: +1-919-513-1494; Fax: +1-919-515-6884.

Received: 10 May 2013; in revised form: 3 July 2013 / Accepted: 4 July 2013 /

Published: 17 July 2013

Abstract: Three feed additives were tested to improve the growth and health of pigs chronically challenged with aflatoxin (AF) and deoxynivalenol (DON). Gilts $(n=225$, $8.8 \pm 0.4 \mathrm{~kg}$ ) were allotted to five treatments: CON (uncontaminated control); MT (contaminated with $150 \mu \mathrm{g} / \mathrm{kg}$ AF and $1100 \mu \mathrm{g} / \mathrm{kg} \mathrm{DON}$ ); A (MT + a clay additive); $\mathrm{B}(\mathrm{MT}+\mathrm{a}$ clay and dried yeast additive); and $\mathrm{C}(\mathrm{MT}+\mathrm{a}$ clay and yeast culture additive). Average daily gain (ADG) and feed intake (ADFI) were recorded for 42 days, blood collected for immune analysis and tissue samples to measure damage. Feeding mycotoxins tended to decrease ADG and altered the immune system through a tendency to increase monocytes and immunoglobulins. Mycotoxins caused tissue damage in the form of liver bile ductule hyperplasia and karyomegaly. The additives in diets A and B reduced mycotoxin effects on the immune system and the liver and showed some ability to improve growth. The diet $\mathrm{C}$ additive played a role in reducing liver damage. Collectively, we conclude that AF and DON can be harmful to the growth and health of pigs consuming 
mycotoxins chronically. The selected feed additives improved pig health and may play a role in pig growth.

Keywords: aflatoxin; clays; deoxynivalenol; pigs; yeast

\section{Introduction}

Mycotoxins are toxic secondary metabolites of fungi commonly found on grains, which can cause severe impacts on animal health and performance [1]. Of 300 to 400 known mycotoxins, aflatoxin (AF) and deoxynivalenol (DON) are two of the most common and harmful for the feed and animal industries [2]. It is estimated that $25 \%$ of the world's crops are contaminated to some extent by mycotoxins, and a survey from the NC Cooperative Extension Service found that $17 \%$ of corn tested was contaminated with levels higher than $20 \mu \mathrm{g} / \mathrm{kg} \mathrm{AF}$, and over $60 \%$ of corn contained DON [3-5]. For both toxins, swine are one of the most sensitive species. As a result of the high contamination of corn by these mycotoxins, pigs may easily consume grains contaminated with AF or DON above the USA FDA action level of $20 \mu \mathrm{g} / \mathrm{kg}$ to $200 \mu \mathrm{g} / \mathrm{kg}$ AF and advisory level of $1000 \mu \mathrm{g} / \mathrm{kg}$ DON for pigs [6]. When consumed, these mycotoxins can decrease pig growth, cause immune dysfunction or damage organs [7-10]. Although the fungi producing AF and DON grow under different environmental conditions, making it unlikely that they contaminate grains at the same time, there is, however, a high likelihood that two grain sources contaminated with AF or DON can be mixed together during feed processing [1]. As a result, pigs may consume a diet co-contaminated with mycotoxins. Together, these mycotoxin may act synergistically to further the negative effects caused to animals $[11,12]$.

One method to reduce the detrimental impact of mycotoxin contamination is the use of feed additives. Clays and yeast components may have the ability to reduce the impact of mycotoxins through binding properties [5,13]. Efficacy of these feed additives can depend on the types of mycotoxins and their concentrations in feed. One type of clay includes montmorillonite, a layered silicate with properties that allows adsorption of the polar AF compound by the exchange of cations $[13,14]$. Previous research has documented that $1 \%$ montmorillonite was able to adsorb $98 \%$ to 99.5\% of AF during an intestinal fluid simulation [14]. Other clays include sodium bentonite and sepiolite. Sodium bentonite is a layered crystalline structured clay formed from volcanic ash and may consist primarily of montmorillonite [15]. Sodium bentonite is often used as a binding agent in the production of pelleted foods. Sepiolite is a silicate clay also commonly used as a pellet binder. Both of these clays have been shown to adsorb nearly all of the existing AF when testing in simulated intestinal fluid [14]. Diatomaceous earth is another material that may be used in the animal health industry. Diatomaceous earth is a sedimentary mineral formed from the skeletal remains of a group of algae called diatoms and contains silica, sodium, magnesium, iron and other trace minerals [16]. Due to its properties, diatomaceous earth is commonly used as an anti-caking agent during feed processing.

Yeasts may also be beneficial during a mycotoxin challenge. Dried brewer's yeast is dried to preserve a portion of the fermenting and adsorptive power of the yeast [17]. This material has mycotoxin absorption abilities, because the yeast cell walls can contain polysaccharides, lipids and 
proteins with absorption centers that bind mycotoxins through hydrogen and ionic bonding or hydrophobic interactions [13]. Yeast cell wall materials have a particular ability to bind mycotoxins, such as DON, zearalenone and ochratoxin [15]. Yeast culture is a second type of yeast additive that may be used to reduce mycotoxin effects. Yeast culture is a dried, fermented product containing small amounts of live yeast and the metabolic products produced by the yeast during fermentation [18]. Yeast culture can act primarily as a probiotic to stimulate the immune system and to improve gut health, in turn reducing mycotoxin effects. It is hypothesized for this current study that pigs eating diets naturally contaminated with $\mathrm{AF}$ and DON together will have reduced weight gain, an altered immune system and increased organ damage, whereas the use of clay and yeast feed additives will reduce these negative effects. The objective of this study was to determine the effects of AF and DON together from naturally contaminated grains on growth, organ health and immune responses of pigs and to investigate the efficacy of three uniquely different types of feed additives to reduce these effects during this mycotoxin challenge.

\section{Results}

\subsection{Growth Performance}

The body weight of pigs did not differ between treatments for all trial weeks, nor did average daily gain (ADG) for the first three weeks (Table 1). During the third week of the trial, feeding mycotoxins tended to lower ADG, but this did not continue during the last two weeks of the trial. However, over the entire 42-day period, pigs consuming mycotoxins tended to have reduced ADG in contrast to pigs not consuming AF and DON. Daily feed intake was not altered by the mycotoxins when considering the entire trial period, and gain-to-feed ratio was also not affected. The addition of the feed additives did not significantly improve the growth of pigs consuming mycotoxins, although the feed additives in diet $\mathrm{A}$ and $\mathrm{B}$ did numerically improve performance.

Table 1. Performance of pigs fed diets containing mycotoxins and various feed additives.

\begin{tabular}{|c|c|c|c|c|c|c|c|}
\hline & \multicolumn{5}{|c|}{ Treatment $^{1}$} & \multirow{2}{*}{ SEM } & \multirow{2}{*}{$p$-Value } \\
\hline & $\mathrm{CON}$ & MT & $\mathbf{A}$ & B & $\mathrm{C}$ & & \\
\hline \multicolumn{8}{|l|}{$\mathrm{BW}, \mathrm{kg}$} \\
\hline day 0 & 8.9 & 8.9 & 8.8 & 8.9 & 8.9 & 0.1 & 0.987 \\
\hline day 7 & 9.7 & 9.8 & 9.6 & 9.9 & 9.8 & 0.2 & 0.880 \\
\hline day 14 & 11.5 & 11.6 & 11.5 & 11.6 & 11.7 & 0.3 & 0.987 \\
\hline day 21 & 13.9 & 13.9 & 13.5 & 14.0 & 14.0 & 0.4 & 0.877 \\
\hline day 28 & 17.6 & 16.7 & 17.2 & 17.0 & 17.2 & 0.4 & 0.733 \\
\hline day 35 & 21.6 & 20.2 & 20.6 & 20.7 & 20.3 & 0.5 & 0.311 \\
\hline day 42 & 26.6 & 24.8 & 25.6 & 25.5 & 25.0 & 0.5 & 0.124 \\
\hline \multicolumn{8}{|l|}{$\mathrm{ADG}, \mathrm{g} / \mathrm{d}$} \\
\hline day 0 to 7 & 114 & 120 & 113 & 144 & 128 & 26 & 0.909 \\
\hline day 7 to 14 & 261 & 261 & 274 & 245 & 281 & 24 & 0.855 \\
\hline day 14 to 21 & 347 & 328 & 281 & 337 & 319 & 30 & 0.567 \\
\hline day 21 to 28 & $518^{a}$ & $401^{\mathrm{b}}$ & $523^{\mathrm{a}}$ & $429^{\mathrm{a}, \mathrm{b}}$ & $457^{\mathrm{a}, \mathrm{b}}$ & 36 & 0.073 \\
\hline day 28 to 35 & 572 & 494 & 496 & 534 & 453 & 36 & 0.183 \\
\hline
\end{tabular}


Table 1. Cont.

\begin{tabular}{|c|c|c|c|c|c|c|c|}
\hline & \multicolumn{5}{|c|}{ Treatment $^{1}$} & \multirow{2}{*}{ SEM } & \multirow{2}{*}{$p$-Value } \\
\hline & CON & MT & $\mathbf{A}$ & B & C & & \\
\hline day 35 to 42 & 724 & 655 & 705 & 674 & 670 & 24 & 0.273 \\
\hline day 0 to 42 & $423^{\mathrm{a}}$ & $377^{\mathrm{b}}$ & $399^{a, b}$ & $394^{\mathrm{a}, \mathrm{b}}$ & $385^{b}$ & 12 & 0.079 \\
\hline \multicolumn{8}{|l|}{ ADFI, g/d } \\
\hline day 0 to 7 & 326 & 308 & 306 & 322 & 317 & 20 & 0.948 \\
\hline day 7 to 14 & 545 & 546 & 541 & 531 & 553 & 29 & 0.988 \\
\hline day 14 to 21 & $730^{a}$ & $622^{b}$ & $643^{b}$ & $637^{\mathrm{b}}$ & $630^{\mathrm{b}}$ & 30 & 0.088 \\
\hline day 21 to 28 & 909 & 838 & 885 & 837 & 866 & 38 & 0.634 \\
\hline day 28 to 35 & 994 & 948 & 1024 & 980 & 936 & 47 & 0.691 \\
\hline day 35 to 42 & 1392 & 1288 & 1349 & 1272 & 1279 & 47 & 0.303 \\
\hline day 0 to 42 & 816 & 759 & 791 & 763 & 764 & 27 & 0.518 \\
\hline \multicolumn{8}{|l|}{ Gain/feed } \\
\hline day 0 to 7 & 0.210 & 0.349 & 0.186 & 0.332 & 0.285 & 0.101 & 0.724 \\
\hline day 7 to 14 & 0.478 & 0.477 & 0.510 & 0.391 & 0.484 & 0.052 & 0.569 \\
\hline day 14 to 21 & 0.484 & 0.529 & 0.432 & 0.535 & 0.520 & 0.046 & 0.487 \\
\hline day 21 to 28 & 0.612 & 0.471 & 0.603 & 0.512 & 0.537 & 0.057 & 0.367 \\
\hline day 28 to 35 & $0.633^{a}$ & $0.512^{b}$ & $0.477^{\mathrm{b}}$ & $0.543^{a, b}$ & $0.469^{b}$ & 0.045 & 0.083 \\
\hline day 35 to 42 & 0.531 & 0.516 & 0.531 & 0.537 & 0.527 & 0.023 & 0.975 \\
\hline day 0 to 42 & 0.524 & 0.495 & 0.507 & 0.518 & 0.502 & 0.012 & 0.469 \\
\hline
\end{tabular}

a,b Means within a row with different superscripts show a tendency to differ $(0.05 \leq p<0.10) ;{ }^{1} \mathrm{CON}$ : uncontaminated control; MT: contaminated with $150 \mu \mathrm{g} / \mathrm{kg}$ AF and $1100 \mu \mathrm{g} / \mathrm{kg}$ deoxynivalenol (DON); $\mathrm{A}: \mathrm{MT}+2 \mathrm{mg} / \mathrm{kg}$ of a clay additive; $\mathrm{B}: \mathrm{MT}+1.5 \mathrm{mg} / \mathrm{kg}$ of a clay and dried yeast additive; $\mathrm{C}: \mathrm{MT}+1.1 \mathrm{mg} / \mathrm{kg}$ of a clay and yeast culture additive. BW, body weight; ADG, average daily gain; ADFI, average daily feed intake.

\subsection{Hematological Measurements}

Hematological analysis on day 28 showed that some changes did occur, due to the mycotoxins (Table 2). Pigs consuming mycotoxins alone had higher blood levels of mean corpuscular hemoglobin (MCH) than pigs not consuming mycotoxins. These pigs also tended to have a higher mean corpuscular hemoglobin concentration (MCHC) and had increased cellular mean corpuscular volume (MCV) than pig consuming the diet without mycotoxins. The three feed additives, in particular, the additive in diet B, significantly reduced the effects of $\mathrm{AF}$ and $\mathrm{DON}$ on $\mathrm{MCH}$ and MCHC. By day 42, pigs consuming mycotoxins had significantly increased hematocrit and a continued increase in $\mathrm{MCH}$ and MCV in contrast to pigs not fed mycotoxins (Table 3). These pigs also had an increased monocyte count. The consumption of the additive in diet A lowered the levels of MCV and monocytes in the blood, but both additives $\mathrm{A}$ and $\mathrm{C}$ actually increased blood concentrations of MCHC, while the additive in $\mathrm{C}$ increased basophil concentration. Pigs fed the additive in diet $\mathrm{B}$ had significantly lower $\mathrm{MCV}$ and monocyte counts without affecting other hematological parameters in the pigs. 
Table 2. Hematology (day 28) of pigs fed diets containing mycotoxins and various feed additives.

\begin{tabular}{|c|c|c|c|c|c|c|c|}
\hline & \multicolumn{5}{|c|}{ Treatment $^{1}$} & \multirow[b]{2}{*}{ SEM } & \multirow[b]{2}{*}{$p$-Value } \\
\hline & CON & MT & $\mathbf{A}$ & B & C & & \\
\hline Hematocrit, \% & 32.9 & 35.1 & 39.6 & 38.6 & 36.3 & 2.4 & 0.421 \\
\hline Hemoglobin, g/dL & 10.3 & 12.0 & 12.7 & 12.3 & 11.6 & 0.8 & 0.297 \\
\hline $\mathrm{MCH}^{2}, \mathrm{pg}$ & $15.9^{\mathrm{a}}$ & $16.8^{\mathrm{c}}$ & $16.8^{\mathrm{c}}$ & $16.1^{\mathrm{a}, \mathrm{b}}$ & $16.6^{\mathrm{b}, \mathrm{c}}$ & 0.2 & 0.009 \\
\hline $\mathrm{MCHC}^{2}, \mathrm{~g} / \mathrm{dL}$ & $32.1^{\mathrm{d}}$ & $32.6^{\mathrm{e}}$ & $32.0^{\mathrm{d}}$ & $32.0^{\mathrm{d}}$ & $32.1^{\mathrm{d}}$ & 0.2 & 0.098 \\
\hline $\mathrm{MCV}^{2}, \mathrm{fL}$ & $49.7^{\mathrm{a}}$ & $51.5^{\mathrm{b}, \mathrm{c}}$ & $52.5^{\mathrm{c}}$ & $50.5^{\mathrm{a}, \mathrm{b}}$ & $51.7^{\mathrm{b}, \mathrm{c}}$ & 0.6 & 0.018 \\
\hline Platelet, $10^{3} / \mu \mathrm{L}$ & 382 & 415 & 359 & 378 & 298 & 39 & 0.277 \\
\hline $\mathrm{RBC}^{2}, 10^{6} / \mu \mathrm{L}$ & 6.63 & 6.82 & 7.52 & 7.58 & 7.01 & 0.43 & 0.423 \\
\hline $\mathrm{WBC}^{2}, 10^{3} / \mu \mathrm{L}$ & 26.2 & 24.1 & 26.3 & 24.7 & 21.8 & 1.5 & 0.236 \\
\hline Basophil, $10^{3} / \mu \mathrm{L}$ & 0.23 & 0.16 & 0.32 & 0.31 & 0.19 & 0.06 & 0.209 \\
\hline Eosinophil, $10^{3} / \mu \mathrm{L}$ & 0.58 & 0.55 & 0.58 & 0.47 & 0.44 & 0.09 & 0.730 \\
\hline Lymphocyte, $10^{3} / \mu \mathrm{L}$ & 11.4 & 10.5 & 12.5 & 11.3 & 10.4 & 0.9 & 0.458 \\
\hline Monocyte, $10^{3} / \mu \mathrm{L}$ & 1.70 & 2.04 & 2.04 & 1.73 & 1.58 & 0.18 & 0.221 \\
\hline Neutrophil, $10^{3} / \mu \mathrm{L}$ & 11.8 & 10.4 & 10.2 & 10.2 & 8.6 & 1.0 & 0.265 \\
\hline
\end{tabular}

${ }^{\mathrm{a}-\mathrm{c}}$ Means within a row with different superscripts differ $(p<0.05)$; ${ }^{\mathrm{d}, \mathrm{e}}$ Means within a row with different superscripts show a tendency to differ $(0.05 \leq p<0.10) ;{ }^{1} \mathrm{CON}$ : uncontaminated control; MT: contaminated with $150 \mu \mathrm{g} / \mathrm{kg} \mathrm{AF}$ and $1100 \mu \mathrm{g} / \mathrm{kg}$ DON; A: MT $+2 \mathrm{mg} / \mathrm{kg}$ of a clay additive; B: MT $+1.5 \mathrm{mg} / \mathrm{kg}$ of a clay and dried yeast additive; C: $\mathrm{MT}+1.1 \mathrm{mg} / \mathrm{kg}$ of a clay and yeast culture additive; ${ }^{2} \mathrm{MCH}$ : mean corpuscular hemoglobin; MCHC: mean corpuscular hemoglobin concentration; MCV: mean corpuscular volume; RBC: red blood cell count; WBC: white blood cell count.

Table 3. Hematology (day 42) of pigs fed diets containing mycotoxins and various feed additives.

\begin{tabular}{|c|c|c|c|c|c|c|c|}
\hline & \multicolumn{5}{|c|}{ Treatment $^{1}$} & \multirow[b]{2}{*}{ SEM } & \multirow[b]{2}{*}{$p$-Value } \\
\hline & CON & MT & $\mathbf{A}$ & B & $\mathbf{C}$ & & \\
\hline Hematocrit, \% & $34.7^{\mathrm{a}}$ & $37.5^{b}$ & $36.5^{\mathrm{ab}}$ & $34.9^{\mathrm{a}}$ & $35.4^{\mathrm{a}}$ & 0.9 & 0.029 \\
\hline Hemoglobin, g/dL & 10.9 & 11.5 & 11.6 & 10.9 & 11.2 & 0.3 & 0.172 \\
\hline $\mathrm{MCH}^{2}, \mathrm{pg}$ & $16.9^{\mathrm{a}}$ & $17.8^{\mathrm{b}, \mathrm{c}}$ & $17.8^{\mathrm{b}, \mathrm{c}}$ & $17.2^{\mathrm{a}, \mathrm{b}}$ & $18.1^{\mathrm{c}}$ & 0.3 & 0.008 \\
\hline $\mathrm{MCHC}^{2}, \mathrm{~g} / \mathrm{dL}$ & $31.4^{\mathrm{d}, \mathrm{e}}$ & $30.7^{\mathrm{d}}$ & $31.8^{\mathrm{e}}$ & $31.2^{\mathrm{d}, \mathrm{e}}$ & $31.9^{\mathrm{e}}$ & 0.4 & 0.072 \\
\hline $\mathrm{MCV}^{2}, \mathrm{fL}$ & $53.9^{\mathrm{a}}$ & $58.1^{\mathrm{c}}$ & $56.0^{\mathrm{b}}$ & $55.3^{\mathrm{a}, \mathrm{b}}$ & $56.8^{\mathrm{b}, \mathrm{c}}$ & 0.7 & 0.001 \\
\hline Platelet, $10^{3} / \mu \mathrm{L}$ & 431 & 410 & 370 & 329 & 369 & 28 & 0.101 \\
\hline $\mathrm{RBC}^{2}, 10^{6} / \mu \mathrm{L}$ & 6.44 & 6.46 & 6.47 & 6.32 & 6.24 & 0.15 & 0.622 \\
\hline $\mathrm{WBC}^{2}, 10^{3} / \mu \mathrm{L}$ & 18.6 & 21.4 & 19.6 & 18.0 & 20.1 & 1.4 & 0.386 \\
\hline Basophil, $10^{3} / \mu \mathrm{L}$ & $0.09^{\mathrm{d}}$ & $0.16^{\mathrm{d}, \mathrm{e}}$ & $0.12^{\mathrm{d}, \mathrm{e}}$ & $0.13^{\mathrm{d}, \mathrm{e}}$ & $0.20^{\mathrm{e}}$ & 0.03 & 0.084 \\
\hline Eosinophil, $10^{3} / \mu \mathrm{L}$ & 0.61 & 0.57 & 0.83 & 0.46 & 0.60 & 0.13 & 0.404 \\
\hline Lymphocyte, $10^{3} / \mu \mathrm{L}$ & 9.56 & 9.18 & 10.10 & 8.83 & 9.49 & 0.53 & 0.513 \\
\hline Monocyte, $10^{3} / \mu \mathrm{L}$ & $0.97^{\mathrm{a}}$ & $1.43^{b}$ & $1.05^{\mathrm{a}}$ & $0.95^{\mathrm{a}}$ & $1.26^{\mathrm{a}, \mathrm{b}}$ & 0.13 & 0.043 \\
\hline Neutrophil, $10^{3} / \mu \mathrm{L}$ & 7.39 & 10.05 & 7.53 & 7.60 & 8.40 & 1.17 & 0.362 \\
\hline
\end{tabular}

${ }^{\mathrm{a}-\mathrm{c}}$ Means within a row with different superscripts differ $(p<0.05) ;{ }^{\mathrm{d}, \mathrm{e}}$ Means within a row with different superscripts tend to differ $(0.05 \leq p<0.10)$; ${ }^{1} \mathrm{CON}$ : uncontaminated control; MT: contaminated with $150 \mu \mathrm{g} / \mathrm{kg}$ AF and $1100 \mu \mathrm{g} / \mathrm{kg} \mathrm{DON}$; A: MT $+2 \mathrm{mg} / \mathrm{kg}$ of a clay additive; B: MT $+1.5 \mathrm{mg} / \mathrm{kg}$ of a clay and dried yeast additive; C: MT $+1.1 \mathrm{mg} / \mathrm{kg}$ of a clay and yeast culture additive; ${ }^{2} \mathrm{MCH}$ : mean corpuscular hemoglobin; $\mathrm{MCHC}$ : mean corpuscular hemoglobin concentration; MCV: mean corpuscular volume; RBC: red blood cell count; WBC: white blood cell count. 


\subsection{Immunological Evaluation}

On day 28, immunological parameters were minimally altered. However, pigs fed the additive in diet $\mathrm{B}$ tended to have an increased serum immunoglobulin (Ig) $\mathrm{G}$ concentration in contrast to pigs consuming only mycotoxins or mycotoxins plus the additive in diet A (Table 4). On day 42, pigs consuming AF and DON tended to have increased $\operatorname{IgG}$ and $\operatorname{IgM}$ compared with pigs consuming the CON or A diets, whereas serum concentrations of IgG and IgM in pigs, the other additives in B and C were intermediate to the mycotoxin contaminated and uncontaminated controls. The cytokine tumor necrosis factor alpha $(\mathrm{TNF} \alpha)$ was not affected by the mycotoxins or the feed additives throughout the trial.

Table 4. Immunological parameters of pigs fed diets containing mycotoxins and various feed additives.

\begin{tabular}{|c|c|c|c|c|c|c|c|}
\hline & \multicolumn{5}{|c|}{ Treatment $^{1}$} & \multirow{2}{*}{ SEM } & \multirow{2}{*}{$p$-Value } \\
\hline & $\mathrm{CON}$ & MT & $\mathbf{A}$ & B & $\mathrm{C}$ & & \\
\hline \multicolumn{8}{|l|}{ Day 28} \\
\hline $\mathrm{IgG}^{2}, \mathrm{mg} / \mathrm{mL}$ & $25.3^{\mathrm{a}, \mathrm{b}}$ & $18.0^{\mathrm{b}}$ & $20.0^{\mathrm{b}}$ & $28.7^{\mathrm{a}}$ & $18.7^{\mathrm{a}, \mathrm{b}}$ & 1.5 & 0.096 \\
\hline $\mathrm{IgM}^{2}, \mathrm{mg} / \mathrm{mL}$ & 2.46 & 2.69 & 2.54 & 2.86 & 2.70 & 0.12 & 0.937 \\
\hline $\mathrm{TNF} \alpha^{2}, p g / m L$ & 131 & 115 & 164 & 141 & 143 & 16 & 0.142 \\
\hline \multicolumn{8}{|l|}{ Day 42} \\
\hline $\mathrm{IgG}, \mathrm{mg} / \mathrm{mL}$ & $10.5^{\mathrm{a}, \mathrm{b}}$ & $15.1^{\mathrm{c}}$ & $8.6^{\mathrm{a}}$ & $13.5^{\mathrm{b}, \mathrm{c}}$ & $11.1^{\mathrm{a}, \mathrm{b}, \mathrm{c}}$ & 0.6 & 0.069 \\
\hline $\mathrm{IgM}, \mathrm{mg} / \mathrm{mL}$ & $3.02^{\mathrm{a}}$ & $4.39^{b}$ & $2.71^{\mathrm{a}}$ & $3.19^{\mathrm{a}, \mathrm{b}}$ & $3.23^{\mathrm{a}, \mathrm{b}}$ & 0.15 & 0.077 \\
\hline $\mathrm{TNF} \alpha, \mathrm{pg} / \mathrm{mL}$ & 118 & 97 & 108 & 132 & 118 & 38 & 0.519 \\
\hline
\end{tabular}

\subsection{Liver Biochemistry}

Liver biochemical parameters measured in the serum were minimally affected by mycotoxin consumption. On day 28, the serum albumin concentration of pigs fed MT was increased, and the additives in diets $\mathrm{B}$ and $\mathrm{C}$ numerically reduced this concentration (Table 5). Mycotoxin consumption without feed additives increased BUN to creatinine ratio, which was reduced by feeding of additive B, and pigs fed MT also had increased serum nitrogen. On day 42, albumin continued to be elevated due to the mycotoxins, and serum calcium was also increased (Table 6). Generally, the addition of the feed additives did not alter the biochemical parameters affected by the mycotoxins. 
Table 5. Serum biochemistry (day 28) of pigs fed diets containing mycotoxins and various feed additives.

\begin{tabular}{|c|c|c|c|c|c|c|c|}
\hline & \multicolumn{5}{|c|}{ Treatment $^{1}$} & \multirow{2}{*}{ SEM } & \multirow{2}{*}{$p$-Valuc } \\
\hline & $\mathrm{CON}$ & MT & $\mathbf{A}$ & B & C & & \\
\hline Albumin, $\mathrm{g} / \mathrm{dL}$ & $2.12^{\mathrm{a}}$ & $2.39^{b}$ & $2.43^{b}$ & $2.17^{\mathrm{a}, \mathrm{b}}$ & $2.29^{\mathrm{a}, \mathrm{b}}$ & 0.08 & 0.043 \\
\hline Albumin:globulin ${ }^{2}$ & $0.62^{\mathrm{a}}$ & $0.70^{\mathrm{a}, \mathrm{b}}$ & $0.77^{b}$ & $0.59^{\mathrm{a}}$ & $0.71^{\mathrm{a}, \mathrm{b}}$ & 0.05 & 0.038 \\
\hline Alk phos ${ }^{2}, \mathrm{U} / \mathrm{L}$ & 227 & 232 & 240 & 205 & 262 & 19 & 0.165 \\
\hline $\mathrm{ALT}^{2}, \mathrm{U} / \mathrm{L}$ & 27.1 & 29.9 & 30.3 & 27.5 & 30.1 & 2.7 & 0.866 \\
\hline $\mathrm{AST}^{2}, \mathrm{U} / \mathrm{L}$ & 32.9 & 41.7 & 44.0 & 39.9 & 38.3 & 3.7 & 0.307 \\
\hline Bilirubin, mg/L & 10.8 & 10.7 & 10.0 & 10.0 & 10.0 & 0.4 & 0.526 \\
\hline BUN:creatinine $^{2}$ & $20.5^{\mathrm{a}}$ & $25.2^{\mathrm{c}}$ & $24.6^{\mathrm{b}, \mathrm{c}}$ & $23.9^{b}$ & $27.4^{\mathrm{c}}$ & 1.2 & 0.006 \\
\hline Calcium, mg/dL & 9.92 & 10.16 & 10.29 & 9.79 & 9.88 & 0.16 & 0.129 \\
\hline Chloride, $\mathrm{mEq} / \mathrm{L}$ & 98.8 & 98.7 & 99.2 & 99.2 & 99.5 & 0.5 & 0.777 \\
\hline Cholesterol, mg/dL & 77.4 & 79.2 & 74.8 & 74.5 & 76.6 & 3.2 & 0.783 \\
\hline $\mathrm{CPK}^{2}, \mathrm{U} / \mathrm{L}$ & 527 & 437 & 768 & 544 & 405 & 125 & 0.246 \\
\hline Creatinine, $\mathrm{mg} / \mathrm{dL}$ & 0.65 & 0.63 & 0.64 & 0.67 & 0.63 & 0.02 & 0.383 \\
\hline Globulin, g/dL & $3.60^{\mathrm{d}, \mathrm{e}}$ & $3.51^{\mathrm{d}, \mathrm{e}}$ & $3.32^{\mathrm{d}}$ & $3.80^{\mathrm{e}}$ & $3.34^{\mathrm{d}}$ & 0.16 & 0.098 \\
\hline Glucose, mg/dL & 94 & 91 & 98 & 94 & 100 & 4 & 0.687 \\
\hline $\mathrm{Na}: \mathrm{K}^{2}$ & 23.9 & 23.8 & 22.5 & 22.9 & 22.9 & 0.7 & 0.260 \\
\hline Nitrogen, mg/dL & $13.2^{\mathrm{a}}$ & $15.5^{b}$ & $15.5^{b}$ & $15.7^{\mathrm{b}}$ & $16.8^{\mathrm{b}}$ & 0.6 & 0.003 \\
\hline Phosphorus, mg/dL & 9.02 & 9.55 & 9.80 & 9.29 & 9.75 & 0.24 & 0.130 \\
\hline Potassium, $\mathrm{mEq} / \mathrm{L}$ & 5.98 & 6.05 & 6.35 & 6.28 & 6.18 & 0.19 & 0.420 \\
\hline Protein, g/dL & 5.72 & 5.90 & 5.75 & 5.97 & 5.63 & 0.13 & 0.222 \\
\hline Sodium, $\mathrm{mEq} / \mathrm{L}$ & 141 & 141 & 141 & 142 & 141 & 1 & 0.975 \\
\hline \multicolumn{8}{|c|}{$\begin{array}{l}{ }^{\mathrm{a}-\mathrm{c}} \text { Means within a row with different superscripts } \operatorname{differ}(p<0.05) ;{ }^{\mathrm{d}, \mathrm{e}} \text { Means within a row with different } \\
\text { superscripts tend to differ }(0.05 \leq p<0.10) ;{ }^{1} \mathrm{CON} \text { : uncontaminated control; MT: contaminated with } \\
150 \mu \mathrm{g} / \mathrm{kg} \mathrm{AF} \text { and } 1,100 \mu \mathrm{g} / \mathrm{kg} \text { DON; } \mathrm{A}: \mathrm{MT}+2 \mathrm{mg} / \mathrm{kg} \text { of a clay additive; } \mathrm{B}: \mathrm{MT}+1.5 \mathrm{mg} / \mathrm{kg} \text { of a clay and } \\
\text { dried yeast additive; } \mathrm{C}: \mathrm{MT}+1.1 \mathrm{mg} / \mathrm{kg} \text { of a clay and yeast culture additive; }{ }^{2} \text { Albumin:globulin: albumin to } \\
\text { globulin ratio; Alk phos: alkaline phosphatase; ALT: alanine aminotransferase; AST: aspartate } \\
\text { aminotransferase; BUN:creatinine: BUN (blood urea nitrogen) to creatinine ratio: CPK: creatine } \\
\text { phosphokinase; Na:K: sodium to potassium ratio. }\end{array}$} \\
\hline
\end{tabular}

Table 6. Serum biochemistry (day 42) of pigs fed diets containing mycotoxins and various feed additives.

\begin{tabular}{|c|c|c|c|c|c|c|c|}
\hline & \multicolumn{5}{|c|}{ Treatment $^{1}$} & \multirow{2}{*}{ SEM } & \multirow{2}{*}{$p$-Value } \\
\hline & CON & MT & $\mathbf{A}$ & B & $\mathrm{C}$ & & \\
\hline Albumin, $\mathrm{g} / \mathrm{dL}$ & $2.49^{\mathrm{a}}$ & $2.80^{\mathrm{b}}$ & $2.94^{b}$ & $2.63^{\mathrm{a}, \mathrm{b}}$ & $2.76^{\mathrm{a}, \mathrm{b}}$ & 0.10 & 0.025 \\
\hline Albumin:globulin ${ }^{2}$ & $0.81^{\mathrm{d}}$ & $0.93^{\mathrm{d}, \mathrm{e}}$ & $0.98^{\mathrm{e}}$ & $0.79^{\mathrm{d}}$ & $0.96^{\mathrm{d}, \mathrm{e}}$ & 0.06 & 0.095 \\
\hline Alk phos $^{2}, \mathrm{U} / \mathrm{L}$ & 233 & 236 & 234 & 209 & 250 & 15 & 0.350 \\
\hline $\mathrm{ALT}^{2}, \mathrm{U} / \mathrm{L}$ & 27.1 & 29.5 & 29.3 & 29.3 & 32.6 & 1.9 & 0.391 \\
\hline $\mathrm{AST}^{2}, \mathrm{U} / \mathrm{L}$ & 31.5 & 38.8 & 36.7 & 46.9 & 42.3 & 4.3 & 0.125 \\
\hline Bilirubin, mg/L & 10.0 & 10.0 & 10.0 & 10.0 & 10.7 & 0.3 & 0.473 \\
\hline BUN:creatinine ${ }^{2}$ & $16.0^{\mathrm{d}}$ & $20.6^{\mathrm{d}, \mathrm{e}}$ & $21.9^{\mathrm{e}}$ & $20.8^{\mathrm{d}, \mathrm{e}}$ & $23.0^{\mathrm{e}}$ & 1.0 & 0.078 \\
\hline Calcium, mg/dL & $9.87^{\mathrm{a}}$ & $10.29^{b, c}$ & $10.53^{\mathrm{c}}$ & $9.93^{\mathrm{a}}$ & $10.12^{\mathrm{a}, \mathrm{b}}$ & 0.13 & 0.002 \\
\hline Chloride, $\mathrm{mEq} / \mathrm{L}$ & 101 & 101 & 102 & 101 & 102 & 1 & 0.576 \\
\hline Cholesterol, mg/dL & 78.7 & 76.9 & 72.8 & 72.6 & 75.2 & 2.4 & 0.389 \\
\hline
\end{tabular}


Table 6. Cont.

\begin{tabular}{lccccccc}
\hline & \multicolumn{9}{c}{ Treatment $^{\mathbf{1}}$} & \multirow{2}{*}{ SEM } & \multirow{2}{*}{-Value } \\
\cline { 2 - 6 } & CON & MT & A & B & C & & \\
\hline CPK $^{2}, \mathrm{U} / \mathrm{L}$ & 656 & 723 & 548 & 636 & 715 & 177 & 0.473 \\
Creatinine, mg/dL & 0.66 & 0.64 & 0.64 & 0.68 & 0.65 & 0.02 & 0.551 \\
Globulin, g/dL & 3.25 & 3.17 & 3.05 & 3.37 & 3.00 & 0.14 & 0.367 \\
Glucose, mg/dL & 111 & 110 & 114 & 105 & 108 & 3 & 0.378 \\
Na:K ${ }^{2}$ & 26.0 & 25.3 & 24.9 & 26.0 & 25.3 & 0.6 & 0.825 \\
Nitrogen, mg/dL & $12.3^{\mathrm{a}}$ & $13.0^{\mathrm{a}, \mathrm{b}}$ & $13.9^{\mathrm{b}, \mathrm{c}}$ & $13.7^{\mathrm{b}, \mathrm{c}}$ & $14.6^{\mathrm{c}}$ & 0.5 & 0.018 \\
Phosphorus, mg/dL & 8.95 & 9.63 & 9.51 & 9.02 & 9.37 & 0.24 & 0.171 \\
Potassium, mEq/L & 5.57 & 5.73 & 5.82 & 5.55 & 5.75 & 0.14 & 0.772 \\
Protein, g/dL & 5.74 & 5.97 & 5.99 & 5.99 & 5.76 & 0.12 & 0.248 \\
Sodium, mEq/L & 143 & 143 & 144 & 143 & 143 & 1 & 0.641 \\
\hline
\end{tabular}

${ }^{\mathrm{a}-\mathrm{c}}$ Means within a row with different superscripts differ $(p<0.05)$; ${ }^{\mathrm{d}, \mathrm{e}}$ Means within a row with different superscripts tend to differ $(0.05 \leq p<0.10)$; ${ }^{1} \mathrm{CON}$ : uncontaminated control; MT: contaminated with $150 \mu \mathrm{g} / \mathrm{kg} \mathrm{AF}$ and $1,100 \mu \mathrm{g} / \mathrm{kg}$ DON; A: MT $+2 \mathrm{mg} / \mathrm{kg}$ of a clay additive; B: MT $+1.5 \mathrm{mg} / \mathrm{kg}$ of a clay and dried yeast additive; $\mathrm{C}: \mathrm{MT}+1.1 \mathrm{mg} / \mathrm{kg}$ of a clay and yeast culture additive; ${ }^{2}$ Albumin:globulin: albumin to globulin ratio; Alk phos: alkaline phosphatase; ALT: alanine aminotransferase; AST: aspartate aminotransferase; BUN:creatinine: BUN to creatinine ratio: CPK: creatine phosphokinase; Na:K: sodium to potassium ratio.

\subsection{Weight, Color and Histology of Internal Organs}

Both liver weight and liver weight as a percent of body weight were increased in pigs fed the mycotoxins, whereas the additive in diet B reduced this effect, so that weights were similar to those in the uncontaminated control (Table 7). Kidney and spleen weights were not different between treatments. Minolta color measurements of lightness $\left(\mathrm{L}^{*}\right)$ and redness $\left(\mathrm{a}^{*}\right)$ for the liver were not altered, but liver yellowness $\left(b^{*}\right)$ tended to be increased in pigs fed feed additives. Kidney and spleen color characteristics were not different among treatments.

Table 7. Tissue weight and color of pigs fed diets containing mycotoxins and various feed additives.

\begin{tabular}{|c|c|c|c|c|c|c|c|}
\hline & \multicolumn{5}{|c|}{ Treatment $^{1}$} & \multirow{2}{*}{ SEM } & \multirow{2}{*}{$p$-Value } \\
\hline & CON & MT & $\mathbf{A}$ & B & C & & \\
\hline \multicolumn{8}{|l|}{ Organ weight, g } \\
\hline Liver & $719^{a}$ & $800^{b}$ & $840^{b}$ & $714^{\mathrm{a}}$ & $778^{a, b}$ & 30 & 0.015 \\
\hline Kidney & 149 & 146 & 159 & 141 & 147 & 7 & 0.432 \\
\hline Spleen & 61.1 & 58.5 & 65.0 & 56.4 & 57.7 & 4.1 & 0.578 \\
\hline \multicolumn{8}{|c|}{ Organs, $\%$ of body weight } \\
\hline Liver & $2.71^{\mathrm{a}}$ & $3.29^{b}$ & $3.31^{\mathrm{b}}$ & $2.80^{\mathrm{a}}$ & $3.14^{b}$ & 0.10 & 0.001 \\
\hline Kidney & 0.56 & 0.60 & 0.62 & 0.55 & 0.59 & 0.02 & 0.131 \\
\hline Spleen & 0.23 & 0.24 & 0.25 & 0.22 & 0.24 & 0.01 & 0.583 \\
\hline \multicolumn{8}{|l|}{ Color liver $^{2}$} \\
\hline Lightness $\left(\mathrm{L}^{*}\right)$ & 34.7 & 35.6 & 35.2 & 35.2 & 35.6 & 0.5 & 0.729 \\
\hline Redness (a*) & 14.0 & 13.8 & 13.8 & 13.7 & 13.9 & 0.2 & 0.904 \\
\hline
\end{tabular}


Table 7. Cont.

\begin{tabular}{cccccccc}
\hline & \multicolumn{9}{c}{ Treatment $^{1}$} & \multirow{2}{*}{ SEM } & \multirow{2}{*}{$\boldsymbol{p}$-Value } \\
\cline { 2 - 6 } & CON & MT & A & B & C & & \\
\hline Yellowness (b*) & $3.17^{\mathrm{a}}$ & $3.60^{\mathrm{a}, \mathrm{b}}$ & $3.90^{\mathrm{a}, \mathrm{b}}$ & $3.94^{\mathrm{a}, \mathrm{b}}$ & $4.65^{\mathrm{b}}$ & 0.37 & 0.083 \\
Color kidney & & & & & & & \\
Lightness (L*) & 45.5 & 45.9 & 46.3 & 47.0 & 45.8 & 0.7 & 0.610 \\
Redness (a*) & 13.2 & 13.5 & 13.1 & 12.3 & 13.4 & 0.6 & 0.550 \\
Yellowness (b*) & 7.69 & 7.34 & 7.76 & 8.88 & 8.29 & 0.46 & 0.144 \\
Color spleen & & & & & & & \\
Lightness (L*) & 35.7 & 35.9 & 36.4 & 37.0 & 36.0 & 0.7 & 0.756 \\
Redness (a*) & 18.1 & 18.4 & 18.1 & 18.3 & 18.4 & 0.3 & 0.847 \\
Yellowness (b*) & 1.89 & 1.87 & 1.79 & 1.75 & 1.71 & 0.21 & 0.970 \\
\hline
\end{tabular}

${ }_{\mathrm{a}, \mathrm{b}}$ Means within a row with different superscripts differ $(p<0.05) ;{ }^{\mathrm{c}, \mathrm{d}}$ Means within a row with different superscripts tend to differ $(0.05 \leq p<0.10) ;{ }^{1} \mathrm{CON}$ : uncontaminated control; MT: contaminated with $150 \mu \mathrm{g} / \mathrm{kg}$ AF and 1,100 $\mu \mathrm{g} / \mathrm{kg}$ DON; A: MT $+2 \mathrm{mg} / \mathrm{kg}$ of a clay additive; B: MT $+1.5 \mathrm{mg} / \mathrm{kg}$ of a clay and dried yeast additive; $\mathrm{C}: \mathrm{MT}+1.1 \mathrm{mg} / \mathrm{kg}$ of a clay and yeast culture additive; ${ }^{2}$ Tissue color measured via Minolta Colorimeter (Konica Minolta, Ramsey, NJ).

Table 8. Percent damage to tissues of pigs fed diets containing mycotoxins and various feed additives.

\begin{tabular}{|c|c|c|c|c|c|c|c|}
\hline & \multicolumn{5}{|c|}{ Treatment $^{1}$} & \multirow{2}{*}{ SEM } & \multirow{2}{*}{$p$-Value } \\
\hline & CON & MT & $\mathbf{A}$ & B & $\mathbf{C}$ & & \\
\hline \multicolumn{8}{|l|}{ Liver $^{2}$} \\
\hline Bile ductule hyperplasia & $2.6^{\mathrm{b}}$ & $5.3^{\mathrm{a}}$ & $3.9^{\mathrm{a}, \mathrm{b}}$ & $3.0^{\mathrm{b}}$ & $4.0^{\mathrm{a}, \mathrm{b}}$ & 0.6 & 0.014 \\
\hline Fibrosis & 3.9 & 3.5 & 4.9 & 3.9 & 4.0 & 0.6 & 0.627 \\
\hline Hydropic degeneration & $8.1^{\mathrm{a}, \mathrm{b}}$ & $9.5^{\mathrm{a}}$ & $6.3^{\mathrm{b}}$ & $9.1^{\mathrm{a}}$ & $8.5^{\mathrm{a}}$ & 0.7 & 0.021 \\
\hline Inflammation & 2.4 & 3.0 & 2.6 & 3.0 & 2.8 & 0.2 & 0.219 \\
\hline Karyomegaly & $2.8^{\mathrm{c}}$ & $29.3^{\mathrm{a}}$ & $11.1^{\mathrm{b}}$ & $5.8 b^{c}$ & $5.5^{\mathrm{b}, \mathrm{c}}$ & 2.8 & 0.001 \\
\hline Necrosis & 2.2 & 2.8 & 2.6 & 3.0 & 2.8 & 0.2 & 0.206 \\
\hline Vacuolation & 3.9 & 6.7 & 5.8 & 4.4 & 5.5 & 0.8 & 0.130 \\
\hline \multicolumn{8}{|l|}{ Kidney $^{2}$} \\
\hline Fibrosis & 2.6 & 3.0 & 2.8 & 2.8 & 2.9 & 0.3 & 0.944 \\
\hline Necrosis & 2.8 & 2.8 & 2.8 & 2.8 & 2.8 & 0.2 & 0.935 \\
\hline Protein casts & 2.6 & 2.8 & 2.8 & 2.6 & 2.6 & 0.3 & 0.922 \\
\hline Regeneration & 2.4 & 3.0 & 2.6 & 2.8 & 2.4 & 0.3 & 0.387 \\
\hline Vacuolation & $2.6^{\mathrm{e}}$ & $3.9^{\mathrm{d}}$ & $3.5^{\mathrm{d}, \mathrm{e}}$ & $3.0^{\mathrm{d}, \mathrm{e}}$ & $2.4^{\mathrm{e}}$ & 0.4 & 0.065 \\
\hline \multicolumn{8}{|c|}{$\begin{array}{l}\text { a-c Means within a row with different superscripts differ }(p<0.05) ;{ }^{\mathrm{de}} \text { Means within a row with different } \\
\text { superscripts show a tendency to differ }(0.05 \leq p<0.10) ;{ }^{1} \mathrm{CON} \text { : uncontaminated control; MT: contaminated } \\
\text { with } 150 \mu \mathrm{g} / \mathrm{kg} \text { AF and } 1100 \mu \mathrm{g} / \mathrm{kg} \text { DON; A: MT }+2 \mathrm{mg} / \mathrm{kg} \text { of a clay additive; B: MT }+1.5 \mathrm{mg} / \mathrm{kg} \text { of a clay } \\
\text { and dried yeast additive; C: MT }+1.1 \mathrm{mg} / \mathrm{kg} \text { of a clay and yeast culture additive; }{ }^{2} \text { Microscopic examinations } \\
\text { indicating percent of damage to tissue: normal to minimal }(0 \% \text { to } 5 \%) \text {; mild }(5 \% \text { to } 15 \%) \text {; moderate }(15 \% \text { to } \\
40 \%) \text {; severe (greater than } 40 \%) \text {. }\end{array}$} \\
\hline
\end{tabular}

Tissue damage occurred by the feeding of the mycotoxins (Table 8). Pigs fed AF and DON had increased hepatic bile ductile hyperplasia, karyomegaly and hydropic degeneration. The additive in diet $\mathrm{B}$ had the strongest ability to reduce the effects of the mycotoxins on the liver. However, the other 
feed additives also reduced karyomegaly. Vacuolation was the only form of kidney damage observed due to the mycotoxins, and in this case, the additive in diet $\mathrm{C}$ reduced this damage. All other measurements of liver and kidney damage were not different between pigs fed MT, CON and the feed additives.

\section{Discussion}

Aflatoxin and DON are mycotoxins that commonly contaminate North American grains, such as corn, wheat and barley $[1,15]$. When ingested by swine, these mycotoxins can reduce growth and feed intake, challenge the immune system and cause organ damage [7,10,19,20]. These mycotoxin effects on pig health can result in significant economic losses for producers. When AF and DON are combined in the diet, they may cause further negative impacts on the animal than when consumed alone. Previous research indicates that these mycotoxin may act synergistically to cause greater negative effects on animals [11,12]. Although the design of the present study did not allow for differentiation of the effects of AF and DON alone or together, these results do provide valuable information on how AF and DON alter pig growth and health when mixed together during feed processing. As a result, this study provides practical insight on how pigs may be affected by mycotoxins under normal feeding practices.

There are many commercially available feed additives with the potential to reduce the toxicity of mycotoxins $[4,13,14]$. Some materials, such as clays, are currently used as anti-caking agents to improve flow during feed processing, but their secondary role may be to serve as mycotoxin binding agents $[15,21]$. The current research aimed to determine the ability of three uniquely different types of feed additives to ameliorate the chronic negative effects of feeding diets containing $150 \mu \mathrm{g} / \mathrm{kg} \mathrm{AF}$ and $1100 \mu \mathrm{g} / \mathrm{kg}$ DON to pigs for 42 days. The feed additive in diet A consisted of montmorillonite clay, whereas the feed additive in diet B was comprised of the clays, sodium bentonite and sepiolite, and also contained a dried brewer's yeast component. Finally, diet $\mathrm{C}$ contained a mixture of diatomaceous earth and yeast culture. Each of these clay and yeast materials may have the ability to reduce the effects of mycotoxins on pigs.

In this study, the impact of including feed additives in the diets without mycotoxins was not investigated, as the researchers were trying only to determine how the three additives differed in their effects on pigs during a mycotoxin challenge. The impact of the feed additives when consumed in uncontaminated diets have been shown previously. Generally, clay additives do not appear to impact the animal either positively or negatively when consumed without mycotoxins. Research conducted by [22] showed that feeding montmorillonite clay to weanling pigs did not alter growth performance. The additions of the clays sodium bentonite, sepiolite or diatomaceous earth have also not been shown to be beneficial or detrimental to performance of swine or poultry when added to a diet uncontaminated by mycotoxins $[16,23,24]$. In mice, clay additives are shown to cause an increase in serum potassium concentrations, potentially due to binding reactions, but this effect is not yet duplicated in pigs or poultry [25]. Supplementing yeast cell material to pig diets not contaminated with mycotoxins can result in variable effects. In some cases, yeast supplementation can increase ADG and ADFI, alter feed-to-gain ratio or enhance the immune system and protect against bacterial infections [26-29]. However, other studies show that supplementation of live yeast or yeast $\beta$-glucan 
does not alter growth performance or provide an immune modulating effect to weanling pigs [28,30,31]. In our current study, we are unable to provide details on the effects of the additives alone, as the design of this study did not include the additives with the uncontaminated feed. However, the aim of our research was not to determine the specific binding properties of these additives, but rather, to determine how these additives impacted pigs when consumed simultaneously during a mycotoxin challenge.

The consumption of AF and DON by pigs has been shown to decrease ADG at both low and high concentrations [10,32-34]. Data from [35] showed that $300 \mu \mathrm{g} / \mathrm{kg}$ AF and $600 \mu \mathrm{g} / \mathrm{kg}$ DON can cause $5 \%$ reductions in the growth of pigs. Over the entire trial period in our study, pigs fed mycotoxins had a 10.8\% decrease in ADG. This result is lower than [10], where pigs fed mycotoxin concentrations of $180 \mu \mathrm{g} / \mathrm{kg}$ AF in combination with $900 \mu \mathrm{g} / \mathrm{kg}$ DON had reduced ADG by $21 \%$. However, AF levels were lower $(150 \mu \mathrm{g} / \mathrm{kg})$ and DON higher $(1100 \mu \mathrm{g} / \mathrm{kg})$ in our present study than the experiment by [10], which may indicate a stronger effect of AF on growth than DON. Other studies found AF and DON effects on ADG comparable to our current study [8,19,36,37]. The addition of three feed additives to the contaminated diet resulted in a numerical increase in ADG, but these values were not significantly different than feeding of AF and DON alone.

Feed intake is shown to decrease when feeding pigs low AF concentrations, as indicated by [33], where feed intake of pigs was reduced 3.5\%, due to $140 \mu \mathrm{g} / \mathrm{kg}$ AF. Deoxynivalenol alone is not shown to decrease ADFI at a low concentration of $280 \mu \mathrm{g} / \mathrm{kg}$ [38]. However, [10] showed that low AF and DON together $(180 \mu \mathrm{g} / \mathrm{kg} \mathrm{AF}, 900 \mu \mathrm{g} / \mathrm{kg}$ DON) tended to reduce ADFI by $15.4 \%$ over a 33 day period $(p=0.061)$. Our current study showed a minimal effect on ADFI. However, the three feed additives did result in a numerical improvement in feed intake, although not significant. Gain-to-feed ratio was generally unaffected, as well, and other research agrees with our findings [10,33,39,40].

Based on these results, it has been determined that at chronic low levels, AF $(150 \mu \mathrm{g} / \mathrm{kg})$ and DON $(1100 \mu \mathrm{g} / \mathrm{kg})$ resulted in minimal effects on growth performance. Although not significantly improving growth parameters, the three feed additives showed potential benefits for reducing mycotoxin effects. Other studies indicate that the clay feed additives can improve the ADG and ADFI of pigs fed 200 to $800 \mu \mathrm{g} / \mathrm{kg} \mathrm{AF}$ [36,37,41]. In contrast, [34] indicated that yeast cell wall material did not improve ADG, ADFI or gain-to-feed ratio. As a result of the previous and current research, it appears that the ability of feed additives to reduce mycotoxin affects is variable, and their function may depend on other factors, such as mycotoxin type, contamination level and pig health status.

To determine how mycotoxins act within the body, hematological, immunological and biochemical variables were determined. Hematological analysis showed a few differences between treatments. The primary effects occurred for $\mathrm{MCH}, \mathrm{MCHC}, \mathrm{MCV}$, hematocrit and monocyte counts. There were some variations in hematology between day 28 and 42; however, more effects were observed as mycotoxin consumption time increased. Although not abnormal levels for pigs of this age $[42,43]$, the hematological differences found for pigs fed mycotoxins do show a general effect on red blood cells (RBC). The measurement of MCHC is the average concentration of hemoglobin in a given volume of RBCs, and MCV represents the average volume of a RBC [44]. These measurements can be important for classification of anemia and RBC disorders. In the current study, pigs fed mycotoxins had increased $\mathrm{MCH}$ and $\mathrm{MCV}$, indicating that the mycotoxins caused a slight increase in RBC volume. Despite the results observed in this current study, previous research has shown no effect on $\mathrm{MCH}, \mathrm{MCHC}$ or $\mathrm{MCV}$ when pigs are fed 280 to $3000 \mu \mathrm{g} / \mathrm{kg}$ DON $[10,38,45]$. Hematocrit, 
which is measured as the concentration of $\mathrm{RBC}$ in a given volume of blood and is related to dehydration [44,46-48], was also higher in pigs fed mycotoxins. This result suggests that pigs consuming AF and DON may have been dehydrated. This effect is confirmed by [49], where increased hematocrit was observed in pigs fed 2200 to $2500 \mu \mathrm{g} / \mathrm{kg}$ DON, but feeding AF alone at $200 \mu \mathrm{g} / \mathrm{kg}$ did not affect hematocrit [37]. Monocytes, a subset of white blood cells (WBCs), were also significantly increased by the mycotoxins. Previous research has found monocytes to be increased in pigs fed high concentrations of DON [49].

The three feed additives had variable effects on the hematological parameters, although the feed additive in treatment $\mathrm{B}$ showed the strongest ability to maintain hematological values closest to the uncontaminated control. However, the addition of both A and B feed additives reduced monocyte levels, which were increased by the mycotoxins. Other research has shown that clays may be beneficial in reducing effects on hematological parameters by AF and DON [15]. Yeast cell materials are also indicated to prevent an increase in monocytes after feeding of AF and DON [34].

Proper function of the immune system is important for growing pigs. The adaptive immune system provides a specific immune response, which includes the production of antibodies, such as IgG and IgM, by B-lymphocytes against a particular pathogen or foreign substance [50]. This adaptive immune response is developed over the lifetime of an individual as an adaptation to infection. In our current study, immunological analysis showed minimal treatment effects on day 28, but tendencies were observed on day 42, where IgG and IgM were increased in pigs fed the mycotoxins. These results indicated that low levels of AF and DON stimulated B-lymphocytes to produce more antibodies. Previously, low levels of 140 to $280 \mu \mathrm{g} / \mathrm{kg}$ AF or 280 to $900 \mu \mathrm{g} / \mathrm{kg}$ DON showed no change in IgG or $\operatorname{IgM}[10,33,38]$. On the other hand, high levels of 2200 to $6800 \mu \mathrm{g} / \mathrm{kg}$ DON have been shown to increase concentrations of $\operatorname{IgA}$ and $\operatorname{IgM}$, but with no effect on $\operatorname{IgG}[8,34,49,51]$. Previous research has shown yeast materials to be beneficial at preventing an increase in $\operatorname{IgG}$ and $\operatorname{IgM}$, due to AF, DON and ZEA (zearalenone) contamination [19,34]. Generally, the addition of the three feed additives to the mycotoxin contaminated diet in our study resulted in immunoglobulin values similar to those in pigs consuming uncontaminated feed. However, the montmorillonite clay product in A showed the strongest ability to reduce immunoglobulin levels. Since clays have a stronger ability to bind AF, these results may indicate that AF had a stronger effect on the immune system of these pigs than DON. On both day 28 and 42, the cytokine TNF $\alpha$ was not altered by the mycotoxin consumption. This cytokine was analyzed as a measure of systemic inflammation, occurring due to the mycotoxins, indicating a pro-inflammatory action of the immune system [52]. Despite a lack of significant difference observed in the current study, previous research does indicate that AF and DON can increase TNF $\alpha$ concentrations in pigs [10].

Similar to the hematological analysis, liver biochemistry showed minimal effects of the mycotoxins and the feed additives. At the end of the study, effects occurred primarily in albumin, calcium and nitrogen levels in the serum. Albumin, which is a major protein synthesized by the liver [53], was increased by mycotoxin consumption. However, as mentioned previously, pigs fed the mycotoxins also showed increased hematocrit concentration, which is the most common cause of increased albumin, due to a concentrating effect in the blood following dehydration [47]. Previous research with mycotoxins shows inconsistencies, where albumin may be increased, decreased or unaltered at both low and high AF and DON consumption [8,10,20,54]. The effect on serum calcium was similar to 
albumin, where mycotoxins were fed alone. The three feed additives did not greatly benefit the pigs in regard to the liver biochemistry. However, it is questioned as to how strongly the liver biochemistry was affected by the mycotoxins, as changes may have been simply due to a dehydration effect rather than the mycotoxins. Further research is needed to determine why the mycotoxins caused changes to the serum biochemistry and if this result is harmful to pigs.

Organ weights were comparable with data found in previous research after feeding pigs ranges of 50 to $1807 \mu \mathrm{g} / \mathrm{kg}$ AF and 750 to $6510 \mu \mathrm{g} / \mathrm{kg}$ DON [9,10,45,55]. In our current study, liver weight as a percent of body weight was increased in pigs consuming mycotoxins, whereas the feed additive in diet B helped to reduce this effect on the liver. Similar results are shown by [39], where $3000 \mu \mathrm{g} / \mathrm{kg}$ $\mathrm{AF}$ increased liver and spleen weights as a percent of body weight. Organ colors were minimally altered; however, tissue damages were observed. It is previously documented that $1000 \mu \mathrm{g} / \mathrm{kg}$ DON causes organ damage, including necrosis, blood vessel thickening and hemorrhage [19,20]. High AF $(3000 \mu \mathrm{g} / \mathrm{kg})$ in the diet is shown to cause liver lesions and vacuolation with portal fibrosis and bile duct hyperplasia [39]. In a previous study by [10], liver fibrosis was the only tissue damage observed when feeding pigs low concentrations of AF and DON. Liver damages were prevalent in our current study for pigs fed the mycotoxin contaminated diet, with increases in hepatic bile ductile hyperplasia and karyomegaly, an increase in nuclear size of a cell [56]. The feed additive in diet B, with clay and dried yeast, was able to significantly reduce both the bile ductile hyperplasia and karyomegaly, whereas the additives in $\mathrm{A}$ and $\mathrm{C}$ reduced only karyomegaly. Mild hydropic degeneration was observed in all treatments, but was lowest in A, indicating that this form of liver damage may have occurred, due to an unknown factor other than the mycotoxin effect, and the clay product in A helped to reduce this damage. Previous research has shown the benefits of montmorillonite clay to reduce multi-organ toxicities in swine diets containing $1300 \mu \mathrm{g} / \mathrm{kg}$ zearalenone [57]; however, our current research shows that the additive in B composed of clay and dried yeast may also be helpful at reducing damages to organs during a mycotoxin challenge.

\section{Experimental Section}

\subsection{Animals, Design and Diets}

Two hundred twenty five gilts $(8.8 \pm 0.4 \mathrm{~kg}$, crossbred pigs, Smithfield Premium Genetics, Rose Hill, NC, USA) were used in this study. They were housed in solid concrete floor indoor pens $(1.42 \mathrm{~m} \times 3.86 \mathrm{~m})$ at the North Carolina Swine Evaluation Station (Clayton, NC, USA). Pigs were randomly assigned to five dietary treatments within 15 weight blocks. Each pen had three pigs.

Corn naturally contaminated with AF $(270 \mu \mathrm{g} / \mathrm{kg})$ and barley naturally contaminated with DON $(30,000 \mu \mathrm{g} / \mathrm{kg})$ were used to make a negative control diet with $150 \mu \mathrm{g} / \mathrm{kg}$ AF and $1100 \mu \mathrm{g} / \mathrm{kg}$ DON (Table 9). This diet was derived from [10], who demonstrated that similar concentrations of AF and DON resulted in at least a $15 \%$ reduction in growth performance and changes in hematological, biochemical, histological and immune parameters. Three feed additives composed of clay and yeast materials were added to the mycotoxin contaminated diet. To determine mycotoxin contamination levels, 10 samples from different bin locations were taken for each ingredient and finished diet [58-60]. The 10 samples were then thoroughly blended together, and two subsamples were collected for 
determination of mycotoxin content. Analysis of the concentrations of aflatoxin, DON and other mycotoxin contamination in the grains and diet samples was conducted by North Dakota State Veterinary Diagnostic Laboratory (Fargo, ND, USA). Concentrations of AF were determined using an Agilent's 1100 series HPLC system with a limit of quantitation of $20 \mu \mathrm{g} / \mathrm{kg}$. The level of DON in contaminated grains was determined using gas chromatography-mass spectrometry with a quantitation limit of $500 \mu \mathrm{g} / \mathrm{kg}$. Non-contaminated corn and barley were also used in order to formulate a diet without mycotoxins.

Pigs were fed experimental diets based on their assigned treatment groups: CON (uncontaminated control); MT (contaminated with $150 \mu \mathrm{g} / \mathrm{kg} \mathrm{AF}$ and $1100 \mu \mathrm{g} / \mathrm{kg}$ DON); A (MT + a clay additive, $2 \mathrm{mg} / \mathrm{kg}$ ); B (MT + a clay and dried yeast additive, $1.5 \mathrm{mg} / \mathrm{kg}$ ); and C (MT + a clay and yeast culture additive, $1.1 \mathrm{mg} / \mathrm{kg}$ ). Levels of additives in the diets were based on the amount recommended by each manufacturer. Diet A contained an additive composed of a processed calcium montmorillonite clay (Calibrin ${ }^{\circledR}$-A Enterosorbent, Amlan International, Chicago, IL, USA). Calibrin ${ }^{\circledR}$-A montmorillonite contains: $70 \%$ to $78 \%$ silicon dioxide, $11 \%$ to $15 \%$ aluminum trioxide, $4 \%$ to $7 \%$ ferric oxide, $2 \%$ to $3 \%$ magnesium oxide, $1 \%$ to $2 \%$ potassium oxide and trace amounts of calcium oxide, sodium oxide and other trace metals. The diet B additive (Unike, Nutriad International NV, Belgium) was composed of sodium bentonite and sepiolite clays along with brewer's dried yeast. The additive in diet C (no commercial name available, Biomin GmbH, San Antonio, TX, USA) contained the clay mineral diatomaceous earth and yeast culture material. This live yeast culture (Saccharomyces cerevisiae) consists of a minimum guaranteed analysis for Saccharomyces cerevisiae of $1.2 \times 10^{10} \mathrm{CFU} / \mathrm{lb}$. During the 42 days of diet administration, all pigs had free access to feed and water. Concentrations of essential nutrients met or exceeded requirements suggested by NRC (1998). During the 42 days, ADG and ADFI were measured. A protocol for the use of animals was approved by the North Carolina State University Animal Care and Use Committee.

Table 9. Composition of experimental diets (as-fed basis).

\begin{tabular}{ccc}
\hline & \multicolumn{2}{c}{ Treatment $^{1}$} \\
\cline { 2 - 3 } & CON & MT \\
\hline Ingredient, \% & 69.42 & 4.42 \\
Ground yellow corn & 3.00 & 0.00 \\
Ground barley $^{2}$ & 0.00 & 65.00 \\
Ground yellow corn with aflatoxin $^{2}$ & 0.00 & 3.00 \\
Ground barley with deoxynivalenol $^{2}$ & 25.00 & 25.00 \\
Soybean meal, dehulled $_{\text {Salt }}$ & 0.30 & 0.30 \\
Vitamin premix $^{3}$ & 0.03 & 0.03 \\
Trace mineral premix $^{3}$ & 0.15 & 0.15 \\
Dicalcium phosphate & 0.90 & 0.90 \\
Ground limestone & 0.70 & 0.70 \\
Poultry fat & 0.50 & 0.50 \\
Calculated composition & & \\
Dry matter, \% & 89.50 & 89.50 \\
ME, Mcal/kg & 3.36 & 3.36 \\
Crude protein, \% & 18.08 & 18.08 \\
\hline
\end{tabular}


Table 9. Cont.

\begin{tabular}{|c|c|c|}
\hline & \multicolumn{2}{|c|}{ Treatment $^{1}$} \\
\hline & CON & MT \\
\hline Lys, \% & 0.95 & 0.95 \\
\hline Cys + Met, $\%$ & 0.61 & 0.61 \\
\hline $\operatorname{Trp}, \%$ & 0.21 & 0.21 \\
\hline Thr, \% & 0.68 & 0.68 \\
\hline Calcium, \% & 0.61 & 0.61 \\
\hline Available phosphorus, \% & 0.23 & 0.23 \\
\hline \multicolumn{3}{|l|}{ Analyzed composition } \\
\hline DM, \% & 88.55 & 89.97 \\
\hline $\mathrm{CP}, \%$ & 18.71 & 19.34 \\
\hline Aflatoxin ${ }^{4}, \mu \mathrm{g} / \mathrm{kg}$ & $<20$ & 150 \\
\hline Deoxynivalenol ${ }^{4}, \mu \mathrm{g} / \mathrm{kg}$ & $<500$ & 1100 \\
\hline Fumonisin ${ }^{4}, \mu \mathrm{g} / \mathrm{kg}$ & $<2000$ & 3000 \\
\hline Zearalenone $^{4}, \mu \mathrm{g} / \mathrm{kg}$ & $<500$ & $<500$ \\
\hline \multicolumn{3}{|c|}{$\begin{array}{l}\text { CON: uncontaminated control; MT: contaminated with } 150 \mu \mathrm{g} / \mathrm{kg} \text { AF and } 1100 \mu \mathrm{g} / \mathrm{kg} \text { DON; } \\
\text { MT }+2 \mathrm{mg} / \mathrm{kg} \text { of a clay additive; B: MT }+1.5 \mathrm{mg} / \mathrm{kg} \text { of a clay and dried yeast additive; } \\
\text { MT }+1.1 \mathrm{mg} / \mathrm{kg} \text { of a clay and yeast culture additive.; }{ }^{2} \text { Corn contained } 270 \mu \mathrm{g} / \mathrm{kg} \text { aflatoxin; Barley } \\
\text { ntained } 30,000 \mu \mathrm{g} / \mathrm{kg} \text { deoxynivalenol; }{ }^{3} \text { The vitamin and trace mineral premixes provided the following per } \\
\text { of complete diet: } 6613.8 \mathrm{IU} \text { vitamin A as vitamin A acetate; } 992.0 \mathrm{IU} \text { vitamin } \mathrm{D}_{3} ; 19.8 \mathrm{IU} \text { vitamin E; } \\
54 \mathrm{mg} \text { vitamin } \mathrm{K} \text { as menadione sodium bisulfate; } 0.03 \mathrm{mg} \text { vitamin } \mathrm{B}_{12} ; 4.63 \mathrm{mg} \text { riboflavin; } 18.52 \mathrm{mg} \\
\text { pantothenic acid as calcium pantothenate; } 24.96 \mathrm{mg} \text { niacin; } 0.07 \mathrm{mg} \text { biotin; } 4.0 \mathrm{mg} \mathrm{Mn} \text { as manganous } \\
\text { ide; } 165 \mathrm{mg} \text { Fe as ferrous sulfate; } 165 \mathrm{mg} \mathrm{Zn} \text { as zinc sulfate; } 16.5 \mathrm{mg} \text { Cu as copper sulfate; } 0.30 \mathrm{mg} \text { I as } \\
\text { aylenediamine dihydroiodide; } 0.30 \mathrm{mg} \text { Se as sodium selenite; }{ }^{4} \text { Dietary mycotoxin concentrations were } \\
\text { alyzed by North Dakota State University Veterinary Diagnostic Laboratory (Fargo, ND, USA) based on an } \\
\text { erage of duplicates of each treatment. The quantitation limit is } 20 \mu \mathrm{g} / \mathrm{kg} \text { for AF, } 500 \mu \mathrm{g} / \mathrm{kg} \text { for DON and } \\
\text { A and } 2000 \mathrm{ug} / \mathrm{kg} \text { for fumonisin. }\end{array}$} \\
\hline
\end{tabular}

\subsection{Blood Sampling}

Blood samples were collected aseptically from the jugular vein of one pig per pen (initial median body weight pig) on days 28 and 42. Blood samples were used for hematological, biochemical and immunological analysis. Blood was collected in Monovette tubes (Sarstedt, Newton, NC, USA) containing ethylenediaminetetraacetic acid (EDTA) for hematological analysis. Tubes without anticoagulant were used to collect serum for measuring liver biochemistry, immunoglobulin and cytokine concentrations. Serum samples were allowed to clot at $4{ }^{\circ} \mathrm{C}$ before centrifuging for $15 \mathrm{~min}$ at $3000 \times g\left(4^{\circ} \mathrm{C}\right)$, and were finally stored at $-80^{\circ} \mathrm{C}$ until analyzed.

\subsection{Hematological Measurements}

Whole blood with EDTA was sent to Antech Diagnostics (Cary, NC, USA) for complete blood count. Measurements included hematocrit, hemoglobin, mean corpuscular hemoglobin $(\mathrm{MCH})$, mean corpuscular hemoglobin concentration (MCHC), mean corpuscular volume (MCV), platelet number, red blood cell (RBC) count, white blood cell (WBC) count, basophils, eosinophils, lymphocytes, monocytes and neutrophils. 


\subsection{Immune Parameters}

Total concentrations of the immunoglobulin subsets, IgG and IgM, were measured via ELISA, as described by the manufacturer (Bethyl, Montgomery, TX, USA). Goat anti-pig IgG or goat anti-pig IgM were used as capture antibodies to coat wells. Serum samples from one pig per pen were diluted to $1: 140,000$ and $1: 20,000$ for $\operatorname{IgG}$ and $\operatorname{IgM}$, respectively, and ELISA analysis was completed in duplicate. Horseradish peroxidase labeled goat anti-pig $\operatorname{IgG}$ or IgM was used as the detection antibody in combination with the TMB (3,3',5,5'-tetramethylbenzidene) enzyme substrate. A stop solution of $0.18 \mathrm{M}$ sulfuric acid $\left(\mathrm{H}_{2} \mathrm{SO}_{4}\right)$ was used to stop the enzyme-substrate reaction. Absorbance was read at $450 \mathrm{~nm}$ using an ELISA plate reader (Synergy HT, Bio-tek instruments) and KC4 data analysis software. Samples were quantified relative to a standard curve constructed with known amounts of pig immunoglobulin subset. Detection limits were 7.8 to $500 \mathrm{ng} / \mathrm{mL}$ for $\mathrm{IgG}$, and 15.6 to $1000 \mathrm{ng} / \mathrm{mL}$ for IgM.

Serum TNF $\alpha$ was measured by ELISA following the manufacturer's procedure (R\&D Systems, Minneapolis, MN, USA). A total of $50 \mu \mathrm{L}$ assay dilutent RD1-63 was added to microplate wells coated with a monoclonal antibody specific to porcine $\mathrm{TNF} \alpha$, followed by $50 \mu \mathrm{L}$ of standard, control or sample. Serum samples from one pig per pen were analyzed. Detection occurred by the use of a color reagent substrate and a stop solution of diluted hydrochloric acid. Absorbance was read at $450 \mathrm{~nm}$ and $540 \mathrm{~nm}$ by an ELISA plate reader and KC4 data analysis software. The detection limit range for TNFa is 2.8 to $5.0 \mathrm{pg} / \mathrm{mL}$.

\subsection{Biochemical Serum Assays}

Concentrations of alanine aminotransferase, albumin, alkaline phosphatase, aspartate aminotransferase, bilirubin, BUN to creatinine ratio (BUN:creatinine), calcium, chloride, cholesterol, creatinine, creatine phosphokinase (CPK), globulin, glucose, nitrogen, phosphorus, potassium, protein, sodium and sodium to potassium ration were measured (Antech Diagnostics, Cary, NC, USA) for determination of liver function.

\subsection{Histological Measurements}

On day 42, the median initial body weight pig from each pen was euthanized via captive bolt to collect liver, kidney and spleen tissues for weight, color and damage evaluation. Tissue color was measured from 3 locations on each tissue via a Minolta Colorimeter (Konica Minolta, Ramsey, NJ, USA), which measured values of lightness $\left(\mathrm{L}^{*}\right)$, redness $\left(\mathrm{a}^{*}\right)$ and yellowness $\left(\mathrm{b}^{*}\right)$. Samples from the liver and kidneys were fixed in $10 \%$ buffered formalin and sent to the North Carolina State University Histopathology Laboratory (College of Veterinary Medicine, Raleigh, NC, USA) for hematoxylin and eosin ( $\mathrm{H} \& \mathrm{E})$ staining and observation of tissue damage. Liver damage measurement included bile ductule hyperplasia, fibrosis, hydropic degeneration, inflammation, karyomegaly, necrosis and vacuolation. Kidney damage measurement included fibrosis, inflammation, necrosis, protein casts, regeneration and vacuolation. Microscopic examinations of tissue damage were measured by an evaluator blinded to treatment, based on the degree of change observed with values of 1 : normal to minimal damage $(0 \%$ to $5 \%$ ); 2 : mild (5\% to $15 \%$ ); 3 : moderate ( $15 \%$ to $40 \%$ ); 4 : severe (higher than $40 \%$ ). 


\subsection{Statistical Analysis}

Data were analyzed using the PROC MIXED procedures of SAS (SAS Inst., Inc., Cary, NC, USA), following a completely randomized block design using initial BW groups as a block. Pen was considered as the experimental unit. Separation of means was completed using the LSMEANS of SAS. Treatment effects were considered statistically significant when $p$-values were less than 0.05 and trends when $p$-values were less than 0.10 and equal or greater than 0.05 .

\section{Conclusions}

Collectively, the results of our study show that feeding pigs $150 \mu \mathrm{g} / \mathrm{kg} \mathrm{AF}$ and $1100 \mu \mathrm{g} / \mathrm{kg}$ DON did impact growth performance, where ADG was reduced by $10.8 \%$, caused some alterations to the immune system and resulted in damage to internal organs. Thus, AF and DON have whole body effects on pigs, even when consuming moderate concentrations of contaminating grains. The addition of feed additives may be beneficial at reducing mycotoxin effects. Although further research may still be needed to understand mechanisms of action, the results of the current study do indicate that both clay and yeast additives can play a role in maintaining pig health under AF and DON challenge. When growth performance was reduced, the three additives numerically increased ADG by up to 6\%. When immune functions were altered by the mycotoxins, both clay and yeast materials helped to minimize immune and inflammatory challenges, as measured by the immune parameters IgG and IgM. Another result of mycotoxin consumption was liver damage. In the current study, all three feed additives played a role in minimizing mycotoxin effects on pigs. However, the montmorillonite clay in diet A appeared to provide the most consistent benefits for minimizing mycotoxin effects on the immune system, whereas the additive in diet $\mathrm{B}$, composed of sodium bentonite, sepiolite and dried yeast, more constantly reduced tissue damages.

Overall, it is concluded that AF and DON can be harmful to pigs when chronically consumed at moderate concentrations of contamination. It is also concluded that the selected feed additives can lessen the negative effects of AF and DON on the immune system and internal organs, subsequently improving the health of the pig, but that the benefits of these additives are variable, and the results are not clear as to which materials provide a stronger protection from the mycotoxins.

\section{Acknowledgments}

The authors acknowledge B. Thacker (Intervet Schering-Plough Animal Health, De Soto, KS 66018) for technical and analytic supports of H3N2 vaccination antibody titer test, C. Hubbard (Warren Wilson College, Ashville, NC 28815) for the donation of barley high in deoxynivalenol and G. Payne (North Carolina State University, Raleigh, NC 27695) for the donation of corn high in aflatoxin. The authors also gratefully acknowledge the financial support provided by North Carolina Ag Foundation.

\section{Conflict of Interest}

The authors declare no conflict of interest. 


\section{References}

1. Council for Agricultural Science and Technology. Mycotoxins: Risks in Plant, Animal, and Human Systems, Task Force Report No. 139; Council for Agricultural Science and Technology: Ames, IA, USA, 2003.

2. Streit, E.; Schatzmayr, G.; Tassis, P.; Tzika E.; Marin, M.; Taranu, I.; Tabuc, C.; Nicolau, A.; Aprodu, I.; Puel, O.; et al. Current situation of mycotoxin contamination and co-occurrence in animal feed-Focus on Europe. Toxins 2012, 4, 788-809.

3. Veldman, B. Mycotoxins in the Animal Production Chain. In Meeting the Mycotoxin Menace; Barug, D., van Egmond, H., Lopez-Garcia, R., van Osenbruggen, T., Visconti, A., Eds.; Wageningen Academic Publishers: Wageningen, The Netherlands, 2004; pp. 275-280.

4. Schatzmayr, G.; Zehner, F.; Taubel, M.; Schatzmayr, D.; Klimitsch, A.; Loibner, A.P.; Binder, E.M. Microbiologicals for deactivating mycotoxins. Mol. Nutr. Food Res. 2006, 50, 543-551.

5. Jones, F.T.; Genter, M.B.; Hagler, W.M.; Hansen, J.A.; Mowrey, B.A.; Poore, M.H.; Whitlow, L.W. Understanding and Coping with Effects of Mycotoxins in Livestock Feed And Forage; North Carolina Cooperative Extension Service: Raleigh, NC, USA, 2007.

6. Food and Drug Administration (FDA). FDA Regulatory Guidance for Toxins and Contaminants; Food and Drug Administration: Silver Springs, MD, USA, 1994.

7. Richard, J.L. Some major mycotoxins and their mycotoxicoses: An overview. Int. J. Food Microbiol. 2007, 119, 3-10.

8. Goyarts, T.; Danicke, S.; Rothkotter, H.J.; Spilke, J.; Tiemann, U.; Schollenberger, M. On the effects of a chronic deoxynivalenol intoxication on performance, haematological and serum parameters of pigs when diets are offered either for ad libitum consumption or fed restrictively. J. Vet. Med. 2005, 52, 305-314.

9. Meissonnier, G.M.; Pinton, P.; Laffitte, J.; Cossalter, A.; Gong, Y.Y.; Wild, C.P.; Bertin, G.; Galtier, P.; Oswald, I.P. Immunotoxicity of aflatoxin B1: Impalirment of the cell-mediated response to vaccine antigen and modulation of cytokine expression. Toxicol. Appl. Pharmacol. 2008, 231, 142-149.

10. Chaytor, A.C.; See, M.T.; Hansen, J.A.; de Souza, A.L.P.; Middleton, T.F.; Kim, S.W. Effects of chronic exposure of diets with reduced concentrations of aflatoxin and deoxynivalenol on growth and immune status of pigs. J. Anim. Sci. 2011, 89, 124-135.

11. Miazzo, R.; Peralta, M.F.; Magnoli, C.; Salvano, M.; Ferrero, S.; Chiacchiera, S.M.; Carvalho, E.C.Q.; Rosa, C.A.R.; Dalcero, A. Efficacy of sodium bentonite as a detoxifier of broiler feed contaminated with aflatoxin and fumonisin. Poultry Sci. 2005, 84, 1-8.

12. Kouadio, J.H.; Mobio, T.A.; Baudrimont, I.; Moukha, S.; Dano, S.D.; Creppy, E.E. Comparative study of cytotoxicity and oxidative stress induced by deoxynivalenol and zearalenone or fumonisin B1 in human intestinal cell line Caco-2. Toxicology 2005, 213, 56-65.

13. Huwig, A.; Freimund, S.; Kappeli, O.; Dutler, H. Mycotoxin detoxification of animal feed by different absorbents. Toxicol. Lett. 2001, 122, 179-188.

14. Ramos, A.-J.; Fink-Gremmels, J.; Hernandez, E. Prevention of toxic effects of mycotoxins by means of nonnutritive adsorbent compounds. J. Food Prot. 1996, 59, 631-641. 
15. Chaytor, A.C.; Hansen, J.A.; van Heugten, E.; See, M.T.; Kim, S.W. Occurrence and decontamination of mycotoxins in swine feed. Asian Aust. J. Anim. Sci. 2011, 24, 723-738.

16. Modirsanei, M.; Mansoori, B.; Khosravi, A.R.; Kiaei, M.M.; Khazraeinia, P.; Farkhoy, M.; Masoumi, Z. Effect of diatomaceous earth on the performance and blood variables of broiler chicks during experimental aflatoxicosis. J. Sci. Food Agric. 2008, 88, 626-632.

17. Jurgens, M.H.; Rikabi, R.A.; Zimmerman, D.R. The effect of dietary active dry yeast supplement on performance of sows during gestation-lactation and their pigs. J. Anim. Sci. 1997, 75, 593-597.

18. Van der Peet-Schwering, C.M.C.; Jansman, A.J.M.; Smidt, H.; Yoon, I. Effects of yeast culture on performance, gut integrity, and blood cell composition of weanling pigs. J. Anim. Sci. 2007, 85, 3099-3109.

19. Cheng, Y.H.; Weng, C.F.; Chen, B.J.; Chang, M.H. Toxicity of different Fusarium mycotoxins on growth performance, immune responses and efficacy of a mycotoxin degrading enzyme in pigs. Anim. Res. 2006, 55, 579-590.

20. Chen, F.; Ma, Y.; Xue, C.; Ma, J.; Xie, Q.; Wang, G.; Bi, Y.; Cao, Y. The combination of deoxynivalenol and zearalenone at permitted feed concentrations causes serious physiological effects in young pigs. J. Vet. Sci. 2008, 9, 39-44.

21. Choy, J.-H.; Choi, S.-J.; Oh, J.-M.; Park, T. Clay minerals and layered double hydroxides for novel biological applications. Appl. Clay Sci. 2007, 36, 122-132.

22. Xia, M.S.; Hu, C.H.; Xu, Z.R. Effects of copper bearing montmorillonite on the growth performance, intestinal microflora and morphology of weanling pigs. Anim. Feed Sci. Technol. 2005, 118, 307-317.

23. Schell, T.C.; Lindemann, M.D.; Kornegay, E.T.; Blodgett, D.J. Effects of feeding aflatoxin-contaminated diets with and without clay to weanling and growing pigs on performance, liver function, and mineral metabolism. J. Anim. Sci. 1993, 71, 1209-1218.

24. Parisini, P.; Martelli, G.; Sardi, L.; Escribano, F. Protein and energy retention in pigs fed diets containing sepiolite. Anim. Feed Sci. Technol. 1999, 79, 155-162.

25. Martin-Kleiner, I.; Flegar-Meštrić, Z.; Zadro, R.; Breljak, D.; Stanović Janda, S.; Stojković, R.; Marušić, M.; Radačić, M.; Boranić, M. The effect of the zeolite clinoptilolite on serum chemistry and hematopoiesis in mice. Food Chem. Toxicol. 2001, 39, 717-727.

26. Mathew, A.G.; Chattin, S.E.; Robbins, C.M.; Golden, D.A. Effects of a direct-fed yeast culture on enteric microbial populations, fermentation acids, and performance of weanling pigs. J. Anim. Sci. 1998, 76, 2138-2145.

27. Kogan, G.; Kocher, A. Role of yeast cell wall polysaccharides in pig nutrition and health protection. Livest. Sci. 2007, 109, 161-165.

28. Dänicke, S.; Goyarts, T.; Valenta, H. On the specific and unspecific effects of a polymeric glucomannan mycotoxin adsorbent on piglets when fed with uncontaminated or with Fusarium toxins contaminated diets. Arch. Anim. Nutr. 2007, 61, 266-275.

29. Eicher, S.D.; McKee, C.A.; Carroll, J.A.; Pajor, E.A. Supplemental vitamin C and yeast cell wall B-glucan as growth enhancers in newborn pigs and as immunomodulators after an endotoxin challenge after weaning. J. Anim. Sci. 2006; 84, 2352-2360. 
30. Dritz, S.S.; Shi, J.; Kielian, T.L.; Goodband, R.D.; Nelssen, J.L.; Tokach, M.D.;. Chengappa, M.M.; Smith, J.E.; Blecha, F. Influence of dietary beta-glucan on rowth performance, nonspecific immunity, and resistance to Streptococcus suis infection in weanling pigs. J. Anim. Sci. 1995, 73, 3341-3350.

31. Van Heugten, E.; Funderburke, D.W.; Dorton, K.L. Growth performance, nutrient digestibility, and fecal microflora in weanling pigs fed live yeast. J. Anim. Sci. 2003, 81, 1004-1012.

32. Harvey, R.B.; Kubena, L.F.; Huff, W.E.; Corrier, D.E.; Clark, D.E.; Phillips, T.D. Effects of aflatoxin, deoxynivalenol, and their combinations in the diets of growing pigs. Am. J. Vet. Res. 1989, 40, 602-607.

33. Van Heugten, E.; Spears, J.W.; Coffey, M.T.; Kegley, E.B.; Qureshi, M.A. The effect of methionine and aflatoxin on immune function in weanling pigs. J. Anim. Sci. 1994, 72, 658-664.

34. Swamy, H.V.L.N.; Smith, T.K.; MacDonald, E.J.; Boermans, H.J.; Squires, E.J. Effects of feeding a blend of grains naturally contaminated with Fusarium mycotoxins on swine performance, brain regional neurochemistry, and serum chemistry and the efficacy of a polymeric glucomannan mycotoxin adsorbent. J. Anim. Sci. 2002, 80, 3257-3267.

35. Dersjant-Li, Y.; Verstegen, M.W.A.; Gerrits, W.J.J. The impact of low concentrations of aflatoxin, deoxynivalenol or fumonisin in diets on growing pigs and poultry. Nutr. Res. Rev. 2003, 16, 223-239.

36. Schell, T.C.; Lindemann, M.D.; Kornegay, E.T.; Blodgett, D.J.; Doerr, J.A. Effectiveness of different types of clay for reducing the detrimental effects of aflatoxin-contaminated diets on performance and serum profiles of weanling pigs. J. Anim. Sci. 1993, 71, 1226-1231.

37. Thieu, N.Q.; Ogle, B.; Pettersson, H. Efficacy of bentonite clay in ameliorating aflatoxicosis in piglets fed aflatoxin contaminated diets. Trop. Anim. Health Prod. 2008, 40, 649-656.

38. Accensi, F.; Pinton, P.; Callu, P.; Abella-Bourges, N.; Guelfi, J.-F.; Grosjean, F.; Oswald, I.P. Ingestion of low doses of deoxynivalenol does not affect hematological, biochemical, or immune responses of piglets. J. Anim. Sci. 2006, 84, 1935-1942.

39. Harvey, R.B.; Kubena, L.F.; Elissalde, M.H.; Corrier, D.E.; Huff, W.E.; Rottinghaus, G.E.; Clement, B.A. Cocontamination of swine diets by aflatoxin and diacetoxyscirpenol. J. Vet. Diagn. Invest. 1991, 3, 155-160.

40. Doll, S.; Danicke, S.; Ueberschar, K.H.; Valenta, H.; Schnurrbusch, U.; Ganter, M.; Klobasa, F.; Flachowsky, G. Effects of graded levels of Fusarium toxin contaminated maize in diets for female weaned piglets. Arch. Anim. Nutr. 2003, 57, 311-334.

41. Lindemann, M.D.; Blodgett, D.J.; Kornegay, E.T.; Schurig, G.G. Potential ameliorators of aflatoxicosis in weanling/growing swine. J. Anim. Sci. 1993, 71, 171-178.

42. Friendship R.M.; Lumsden, J.H.; McMillan, I.; Wilson, M.R. Hematology and biochemistry reference values for Ontario swine. Can. J. Comp. Med. 1984, 48, 390-393.

43. Klem, T.B.; Bleken, E.; Morberg, H.; Thoresen, S.I.; Framstad, T. Hematologic and biochemical reference intervals for Norwegian crossbreed grower pigs. Vet. Clin. Path. 2009, 39, 221-226.

44. Perkins, S.L. Examination of the Blood and Bone Marrow. In Wintrobe's Clinical Hematology, 12th ed.; Greer, J.P., Foerster, J., Rodgers, G.M., Paraskevas, F., Glader, B., Arber, D.A., Means, R.T., Jr., Eds; Lippincott Williams and Wilkins: Philadelphia, PA, USA, 2009; pp. 1-781. 
45. Rotter, B.A.; Thompson, B.K.; Lessard, M.; Trenholm, H.L.; Tryphona, H. Influence of low-level exposure to Fusarium mycotoxins on selected immunological and hematological parameters in young swine. Fund. Appl. Toxicol. 1994, 23, 117-124.

46. Dal Santo, G. Hematology Procedures. In A Laboratory Basis for Anesthesiology; Piccin Nuova Libraria: Padua, Italy, 1993; pp. 7-26.

47. Kaneko, J.J.; Harvey, J.W.; Bruss, M. Serum Proteins and the Dysproteinemias. In Clinical Biochemistry of Domestic Animals, 5th ed.; Academic Press: San Diego,CA, USA, 1997; pp. 117-137.

48. Stockham, S.L.; Scott, M.A. Proteins. In Fundamentals of Veterinary Clinical Pathology; Blackwell: Ames, IA, USA, 2002; pp. 268-269.

49. Pinton, P.; Accensi, F.; Beauchamp, E.; Cossalter, A.; Callu, P.; Grosjean, F.; Oswald, I.P. Ingestion of deoxynivalenol (DON) contaminated feed alters the pig vaccinal immune responses. Toxicol. Lett. 2008, 177, 215-222.

50. Murphy, K.; Travers, P.; Walport, M. Janeway's Immunobiology, 7th ed.; Garland Science: New York, NY, USA, 2008.

51. Tiemann, U.; Brüssow, K.P.; Jonas, L.; Pöhland, R.; Schneider, F.; Dänicke, S. Effects of diets with cereal grains contaminated by graded levels of two Fusarium toxins on selected immunological and histological measurements in the spleen of gilts. J. Anim. Sci. 2006, 84, 236-245.

52. Wood, P. Understanding Immunology, 2nd ed.; Pearson Education Limited: Harlow, UK, 2006.

53. Limdi, J.K.; Hyde, G.M. Evaluation of abnormal liver function tests. Postgrad. Med. J. 2003, 79, 307-312.

54. Young, L.G.; McGirr, L.; Valli, V.E.; Lumsden, J.H.; Lun, A. Vomitoxin in corn fed to young pigs. J. Anim. Sci. 1983, 57, 655-664.

55. Dilkin, P.; Zorzete, P.; Mallmann, C.A.; Gomes, J.D.F.; Utiyama, C.E.; Oetting, L.L.; Correa, B. Toxicological effects of chronic low doses of aflatoxin B1 and fumonisin B1-containing Fusarium moniliforme culture material in weaned piglets. Food Chem. Toxicol. 2003, 41, 1345-1353.

56. Haschek, W.M.; Wallig, M.A.; Rousseaux, C.G. The Liver. In Fundamentals of Toxicologic Pathology, 2nd ed.; Academic Press: London, UK, 2010; p. 221.

57. Jiang, S.; Yang, Z.; Yang, W.; Gao, J.; Liu, F.; Chen, C.C.; Chi, F. Physiopathological effects of zearalenone in post-weaning female piglets with or without montmorillonite clay adsorbent. Livest. Sci. 2010, 131, 130-136.

58. Vincelli, P.; Parker, G.; McNeill, S. Aflatoxins in Corn; University of Kentucky Cooperative Extension Service: Lexington, KY, USA, 1995.

59. Munkvold, G.; Hurburgh, C.; Meyer, J. Aflatoxins in Corn; Iowa State University Extension: Ames, IA, USA, 2005.

60. Whitaker, T.B.; Slate, A.B.; Johansson, A.S. Sampling Feeds for Mycotoxin Analysis. In The Mycotoxin Blue Book; Diaz, D., Ed.; Nottingham University Press: England, UK, 2005; pp. 1-23.

(C) 2013 by the authors; licensee MDPI, Basel, Switzerland. This article is an open access article distributed under the terms and conditions of the Creative Commons Attribution license (http://creativecommons.org/licenses/by/3.0/). 